\title{
A Social Identity and Social Power Perspective on Terrorism
}

\section{by Joshua D. Wright}

\section{(cc) $\mathrm{BY}$}

This work is licensed under a Creative Commons Attribution 3.0 License.

\begin{abstract}
This article presents a theoretical framework for understanding terrorism that is grounded in experimental work on social identity and social power. It is suggested that social identity salience and social power may be harnessed to reduce terrorist activity by reducing perceptions of threat from the view of terrorist organizations, by reducing perceived threat of terrorist activity from the view of potential targets, and by addressing distributions of and susceptibility to social power as it relates to acceptability of parochial altruism.
\end{abstract}

Keywords: social identity, social power, terrorism, counter-terrorism, religious terrorism, parochial altruism

Formal theory building in the field of terrorism studies appears relatively absent. This is unfortunate within the social psychological perspective that "nothing is so practical as a good theory" (Lewin, 1943, p. 35). The reciprocal relationship between theory and practice allows for the extraction of intergroup theories from the social sciences, and in particular the field of social psychology, to the field of terrorism studies. Once extracted, theory guides practical solutions and allows for field-testing, a necessary evaluation for the efficacy of counter-terrorism policy. However, without formal theoretical frameworks within the field of terrorism studies it is difficult to examine efficacy in research paradigms or to develop rigorous approaches to policy. Within terrorism studies, religious terrorism is a popular concern as evidenced by articles in the New York Times addressing religious terrorism (Hinnant et al., 2015; Sayare, 2011), and ISIS (Schmitt, 2015), despite that the majority of terrorism is not of a religious nature (Piazza, 2009). Religious terrorism is the primary concern of Western governments, especially the United States, and also of countries in the Middle East, which are currently struggling with the Islamic State. Religious terrorism is unique in that religious appeals may resonate with large masses of people given the current state of religion in the world (Pew Research Center, 2012). Likewise, religion and terrorism are international in scope, crossing national boundaries, and in the case of the Islamic State, attempting to create new boundaries. Social identity theory and theories of social power have strong support within psychology and intergroup relations, have theoretical use in understanding terrorism, and may be used as frameworks for counter-terrorism policy. Both theoretical frameworks may inform strategies for reducing religious terrorism. Three particular implications are discussed: reducing threatening circumstances that elicit terrorist actions, reducing out-of-proportion aggressive responses to terrorism that spur a cycle of violence, and eliminating the prevalent view of parochial altruism.

\section{Social Identity Theory}

Social identity theory is a broad theory of intergroup relations, which suggests that our social categories help determine our perceptions of events and determine our social actions (Tajfel \& Turner, 1979). When conflicts 


\section{Journal of Terrorism Research}

are considered between two or more distinct social categories, or membership groups, this has implications for whether a person perceives stressors as threatening (Branscombe, Ellemers, Spears, \& Doosje, 1999; Haslam \& Reicher, 2006). Because social categorization acts as a cognitive mechanism that helps determine perceptions and social actions (Tajfel \& Turner, 1979), an activation of cognitions relevant to a person's social category can drive behavior according to what is defined as the intergroup continuum of behavior (Tajfel \& Turner, 1979; Tajfel \& Turner, 1986). This means that behavior is guided by factors of social identity (i.e., beliefs and values derived from group membership) rather than interpersonal factors. Some evidence suggests that when social identity is salient, perceived threat will more likely result in aggressive and retaliatory responses (Fischer, Haslam, \& Smith, 2010) and this has been applied to religious identity (Ysseldyk, Matheson, \& Anisman, 2011). The cognitive mechanism of social identity lends itself to both reducing threatening circumstances that may heighten terrorist organizations' desires for devastating action and for reducing retaliatory responses to terrorist action that may be out of proportion to actual events. The former can be accomplished by policy that reduces the perception of forced western culture on the Middle East and reduces perceptions that the West is using its military power to unfairly extort resources from the Middle East. The latter may be accomplished by the leadership of those targetted by these acts of terrorism through deemphasizing in-group homogeneity.

\section{Intervening in Perceived Threat}

One implication of social identity theory to understanding terrorist activity is perception of threat. Perceiving actions as threatening, especially when perceived as intentional and malicious can cause reactive aggression (Geen, 2001). When a social identity is salient, perceptions that an action is threatening will be enhanced. Evidence for this phenomenon can be seen through two experimental studies. Fischer, Haslam, and Smith (2010) conducted an experimental study on women in Britain in which symbolic threats were presented as news articles to participants and social identity salience was manipulated experimentally. Participants were split into two groups; half listed three things they have in common and three things they do not have in common with other women (i.e., gender identity salience). The other half listed three things they have in common and three things they do not have in common with British people in general (i.e., British identity salience). Participants were then presented with photographs and a statement related to either the July 2005 London bombings (i.e., national identity threat) or with photographs and a statement related to the Taliban's treatment of women (i.e., gender identity threat). Participants were then measured on aggression and attitudes toward retaliatory actions. Results indicated that perceived threat was highest when the salient identity corresponded with the threat (e.g., gender identity salience and presented with the article about the Taliban's treatment of women). Additionally, results suggested that aggression and support for retaliatory reactions were both highest when the salient social identity corresponded with the threat.

Religious identity is a particularly powerful social identity because it is built upon fundamental beliefs and values and anchored within a sacred and eternal worldview (Beit-Hallahmi, 2015; Ysseldyk, Matheson, \& Anisman, 2010). Religious identity should help shape social-psychological processes and guide behaviors according to religious group norms and beliefs (Sedikides \& Gebauer, 2013; Ysseldyk et al., 2010). Ysseldyk et al. (2011) extended the findings of Fischer et al. (2010) by testing its predictions specifically with religious identity. In a sample of Christians and Muslims, participants were presented with a fictitious article suggesting that the majority of the population felt coldly toward participants' respective religious group and suggesting that the government was going to use this information to reduce resources available to 


\section{Journal of Terrorism Research}

participants' respective religious groups. Following, participants were assessed on negative emotions and confrontation intentions. Results suggested that participants with an intrinsic religious orientation (i.e., those looking to religion for spiritual guidance and meaning) expressed increased anger and increased intentions for confrontation. Ysseldyk et al. (2011) suggest that, "threats directly targeting one's religious group may evoke more active responses from those for whom the belief system is central to their identity" (p. 140).

To summarize, if religious identity is central to the identity of religious terrorists and the religious identity is salient, threats may be perceived as more relevant to the activated and important identity, resulting in increased anger and more support for retaliatory or confrontational interactions. This suggests that one method of reducing terrorism may be through reducing perceived threat that highly religious groups perceive from the West. The mechanism suggests that this may be accomplished through eliminating the threat or reducing the salience of or importance of religious identity to terrorist group members. While the empirical studies discussed above measure support for retaliation and confrontation intentions at the individual level, an aggregation of these reactions in large groups has the potential to be particularly devastating. Changes at the national level (e.g., framing political discourse), may go a long way in reducing individual level reactions. A few general suggestions are provided for discussion. First, the West needs to redefine its perceived role in the Middle East away from protecting the interests of the West and toward a definition that places the people of the Middle East as the purpose of the West's involvement. When Western involvement is framed as war (i.e., the "war on terror"), this may increase perceived threat by Islamic organizations, who may perceive this discourse as a "war on Islamic tradition" or as implicated by George W. Bush, a crusade (The White House, Office of the Press Secretary, 2001). Determining means of increasing perceptions of this redefinition would be a future avenue for communication and policy oriented research.

As a second general suggestion, the importance of religious identity should be de-emphasized. The media and politicians have emphasized the Islamic nature of terrorism (despite this connection being out of proportion within the context of international terrorism), which may continually enhance perceptions of threat through the process of social identity salience. A clear example is the case of the terrorist attacks against Charlie Hebdo, in which the newspaper ran cartoons depicting the prophet Muhammad, which are viewed as highly defamatory to the Muslim community. Within a radical view of Islam in which Islam is not only religion, but also theocracy, this defamation requires punishment and radical Islamists delivered their interpretation of punishment in 2011 (Sayare, 2011) and 2015 (Hinnant et al., 2015). The root cause can be viewed as perceptions of threat being enhanced through a correspondence between the threat and the relevant social identity, being Muslim.

What has been presented is a reflection of theoretical developments in social identity processes, perceptions of threat, and responses to perceived threat. However, there is a cycle of threat to consider, in which perceived threat by Islamic organizations enhances retaliatory responses, followed by increased perceived threat by the targets of the terrorism, enhancing perceptions of threat by the targets, and leading to further retaliatory action. Thus, another point of intervention is through reducing social identity salience in the target population following a terrorist attack.

\section{Reducing Social Identity Salience}

As Fischer et al. (2010) describe, "psychological and behavioral responses to terrorism depend on both the salient social identity of potential targets as well as the perceived social aims of the terrorists" (p. 148). Thus those in positions of power can redefine acts of terrorism for purposes of either increasing support for 


\section{Journal of Terrorism Research}

retaliatory action (e.g., the emphasis of the Bush administration following 9/11) or can be redefined for the purposes of reducing retaliatory action by downplaying the shared social identity of the targets (Livingstone, Gilbert, Haslam, \& Sweetman, June, 2010). Shaw, Quezada, and Zárate (2011) evaluated Christian participants in the extent to which their religious identity defined who they were. Participants were then randomly assigned to conditions in which they read an adapted version of a real letter written by Osama Bin Laden describing the reasons behind the 9/11 terrorist attacks. In one condition this letter expressed that the attacks were committed for religious reasons. In a second condition the attack was framed as committed for geopolitical reasons. A control condition read about the drug war in Mexico. Results indicated that when the 9/11 attacks were framed as a religious conflict, the more strongly participants identified with their Christian identity, the more strongly they expressed support for violent warfare against the Middle East. The framing of terrorist action matters with regard to the extent that people evaluate threatening circumstances and the extent to which retaliation is supported.

A relevant example of politics enhancing social identity salience in order to promote support for retaliatory action can be seen in the case of the weeks and months following September 11, 2001. The Bush administration consistently used the process of social identity salience by emphasizing the shared attributes of the social group (i.e., emphasizing a solidified and homogenous America) which focused attention to the relevance of the threat to all members (Fischer et al., 2010; Reicher, Haslam, \& Platow, 2007), and generated immediate large-scale support for retaliatory action as evidenced by gallop polls demonstrating a $93 \%$ approval by January 2002 (Gallup, 2014). It must be noted that social identity salience in the American population, especially of the populations' "American" identity would have been enhanced with or without the Bush administration's framing of events. However, I argue that the particular framing of the discourse further enhanced social identity salience, especially with regard to religious identity through the administration's use of religious language (Edgerton, Hart, \& Hassencahl, 2007). Additionally, realpolitik and theory often diverge. The theories explored here focus on the processes at work within the dynamic interplay between terrorism, society, and politics, enlightening these processes. The exploration of these processes in line with current experimental work in social psychology does not imply prioritizing any particular political goal (e.g., involvement in Afghanistan), but only enlightens the processes underlying the decisions with regard to political goals related to terrorism and the support for these positions within a social identity framework. Social identity salience has the potential to be altered by both politicians and the media. A focus on reducing salience of the threatened social identity (e.g., American identity) in the immediate aftermath of terrorist action may reduce retaliatory action, which in some cases may be out of proportion to the reality of particular threats. The majority of terrorism is not religious in nature and the majority of terrorists, including religious terrorist groups, are primarily targeting other Muslims in Muslim dominated regions, not Westerners (LaFree \& Dugan, 2007). However, American media has solidified the fear of terrorism through homogenizing the targets (i.e., Americans), increasing social identity salience, increasing the perceptions of threat, and increasing hostility to the Middle East and Muslims (Choma, Hodson, \& Costello, 2012; Helbling, 2013).

\section{Social Power and Parochial Altruism}

Social identity salience is one mechanism and theoretical perspective that easily adapts itself to terrorism studies. However, changing social identity salience and reducing perceptions of threat on part of the terrorist group or potential terrorist group may require the use of social power. As in the case of the targets of 


\section{Journal of Terrorism Research}

terrorism, this requires action on part of the leadership. Those with social power have the greatest ability to make changes to social identity salience. Furthermore, social power can be used to alter the perceived notion of parochial altruism.

Altruism is often defined in relation to terrorism as extreme altruism or parochial altruism (Choi \& Bowles, 2007), and usually manifests itself in the form of suicide attacks or martyrdom. This method of terrorism is new, only becoming prominent during the current wave of religious terrorism (Rapoport, 2002). Parochialism - hostility to out-group members, and altruism-sacrificing benefits to the self for the in-group, combine to be extremely devastating, and partially explains why religious terrorist attacks have casualty rates more than four times any other type of terrorism (Piazza, 2009). The parochial altruism hypothesis that religious terrorists engage in violence out of moral obligations to the in-group, rather than cost-benefit analysis, has empirical support. Palestinian adults with ties to Hamas or Palestinian Islamic Jihad rate delaying a planned suicide attack as more acceptable if it is for the purpose of looking after an ill family member than for the purpose of protecting the family from death by retaliation (Ginges \& Atran, 2009). Additionally, the same participants overwhelmingly rated it unacceptable to ask for compensation following martyrdom (Ginges \& Atran, 2009). This appears to support the notion that suicide attacks are carried out for reasons of moral obligation rather than for instrumental, rational reasons.

Being motivated by moral reasoning over instrumental reasoning may be further supported by evidence suggesting that terrorism is generally not productive as measured by terrorist organizations achieving their goals (Abrahms, 2006). Parochial altruism does not appear to be about increasing success rates toward political goals, but rather about upholding perceived moral obligations. If moral obligations, rather than instrumental reasoning, primarily dictate religious terrorism then social power can be used to intervene. Parochial altruism needs to be redefined by the power structure in societies where terrorism is nurtured. Power is succinctly defined as potential control over others outcomes (Fiske \& Berdahl, 2007), but power can take a number of different forms. French and Raven (1959) described five bases of power: reward power, coercive power, legitimate power, referent power, and expert power. Reward power is based upon the perception that an "other" can mediate rewards. For example, religious leaders have the power to define and mediate access to spiritual realms. The Catholic Church historically used its control of the afterlife to encourage payments to the Church through the guise of indulgences (i.e., selling access to heaven). Similarly, the power structure of Islam controls mediation between Allah and the spiritual world, defining what actions inherit access to the spiritual world. Similar to reward power is coercive power, or the ability to mediate punishments. In the same manner that religious leaders can mediate access to spiritual rewards, they can mediate avoidance of spiritual punishments.

Legitimate power refers to the perception that an "other" has the right to prescribe behavior. This can be wielded indirectly. For instance, believers may perceive Allah to have divine right to dictate behavior and Islamic clerics have authority to prescribe behavior on Allah's behalf. Referent power simply exists through a shared identification, in this case Islam. And finally, expert power describes a perception that one has special knowledge or insight. For religion, power often comes in the form of control of the afterlife. When forms of power are combined with spiritual rewards and punishments, power can become intensified. With social power comes social responsibility, and the power structure of Islam needs to enforce its religious power (e.g., spiritual rewards for martyrdom) to downplay terrorism as an act of parochial altruism or martyrdom. Perhaps, this is easier described theoretically than in practice, but it leaves open the role of the Muslim world to condemn altruistic parochialism in the form of suicide terrorism as an action deserving of spiritual 
reward. This can theoretically be accomplished in two ways: altering the acceptability of behavior through the power holders or through re-distributed power. How might power be re-distributed in the religious community?

One notion stems from the evidence that most religious terrorists connected to the Jihad movement or to Al-Qaeda networks are not particularly knowledgeable about Islam, nor do they generally come from religious backgrounds (Bakker, 2006; Stern, 2010). In fact, some samples estimate that only about half are from religious backgrounds (Bakker, 2006). This suggests a divergent power between potential terrorists and the religious power holders, in which expert and legitimate power are comparatively enhanced by the lack of knowledge of potential terrorists, and thus a need to rely on interpretations provided by the power holders. Terrorism and counter-terrorism research may find that French and Raven's taxonomy of power lends itself to identifying potential terrorists by studying what types of people are susceptible to those forms of power most intimately tied to the supernatural. Bertram Raven suggests that levels of complexity in moral reasoning may be one such useful approach (Raven, 1999).

\section{Conclusion}

This brief perspective presents a theory driven approach to terrorism and counter-terrorism, suggesting that social identity theory and social power can inform investigation of the causes of terrorism, while providing insight into avenues for terrorism reduction. Theoretically, social identity salience enhances perceptions of threat and this lends itself to approaching counter-terrorism through reducing the focus on shared social characteristics in order to reduce perceptions of threat by terrorist organizations, and subsequently, reducing willingness to engage in terrorist action against civilian targets. This may take the form of encouraging restraint in purposefully ridiculing deeply revered figures and beliefs of religious groups. However, it is not plausible that all terrorist activity will be prevented, nor is it plausible or desirable to overly restrain free speech in attempting to do so. Certainly, a balanced approach between safety and free speech is necessary. Social identity salience also lends itself to the same process of threat reduction and reduced desire for retaliatory action within the social groups targeted by terrorist action.

Those with social power can most appropriately access mechanisms by which social identity salience can be enhanced or reduced (e.g., leadership and social media). Social power also has implications for understanding why parochial altruism has become a powerful form of terrorist activity primarily in the wave of religious terrorism. Research and policy may focus efforts on identifying factors that cause people to be susceptible to forms of social power, such as lacking proper knowledge of religious principles, or particular levels of moral reasoning. In conclusion, applying social identity theory and theories of social power to discussions of religious terrorism may increase the field's understanding of causes of, responses to, and solutions to terrorism.

\section{About the author}

Joshua D. Wright is a doctoral candidate in social psychology and the collaborative program in migration and ethnic relations at the University of Western Ontario. His research addresses how the cognitive process of social identity salience affects aggression, retaliation, and emotion following social identity threat. This research is integrated within the context of religion and violence, including terrorism. He was awarded the International 


\section{Journal of Terrorism Research}

Council of Psychologist's Bain-Sukemune Early Career International Psychology Award for his work in the area of religion and violence.

\section{References}

Abrahms, M. (2006). Why terrorism does not work. International Security, 31(2), 42-78.

Bakker, E. (2006). Jihadi terrorists in Europe: Their characteristics and the circumstances in which they joined the jihad: An exploratory study The Hague: Clingendael Institute.

Beit-Hallahmi, B. (2015). Psychological perspectives on religion and religiosity. New York, NY: Routledge.

Branscombe, N. R., Ellemers, N., Spears, R., \& Doosje, B. (1999). The context and content of social identity threat. In N. Ellemers, R. Spears \& B. Doosje (Eds.), Social identity: Context, commitment, content (pp. 35-58). Oxford, England: Blackwell Science.

Choi, J.-K., \& Bowles, S. (2007). The coevolution of parochial altruism and war. Science, 318, 636-640.

Choma, B. L., Hodson, G., \& Costello, K. (2012). Intergroup disgust sensitivity as a predictor of islamophobia: The modulating effect of fear. Journal of Experimental Social Psychology, 48(2), 499-506.

Edgerton, G. R., Hart, W. B., \& Hassencahl, F. (2007). Televising 9/11 and its aftermath: The framing of George W. Bush's faith-based politics of good and evil. In M. F. Norden (Ed.), The Changing Face of Evil in Film and Television (pp. 195-214). Amsterdam: Editions Rodopi.

Fischer, P., Haslam, S. A., \& Smith, L. (2010). "If you wrong us, shall we not revenge?" Social identity salience moderates support for retaliation in response to collective threat. Group Dynamics: Theory, Research, and Practice, 14(2), 143-150.

Fiske, S. T., \& Berdahl, J. (2007). Social power. In A. W. Kruglanski \& E. T. Higgins (Eds.), Social psychology: Handbook of basic principles (2nd ed., pp. 678-692).

French, J. R., \& Raven, B. (1959). The bases of social power. In D. Cartwright (Ed.), Studies in social power (pp. 150-167). Oxford, England: University of Michigan press.

Gallup. (2014). War on Terror. from http://www.gallup.com/poll/5257/war-terrorism.aspx

Geen, R. G. (2001). Human Aggression. New York, NY: Open University Press and McGraw Hill.

Ginges, J., \& Atran, S. (2009). What motivates participation in violent political action. Annals of the New York Academy of Sciences, 1167(1), 115-123.

Haslam, S. A., \& Reicher, S. (2006). Stressing the group: social identity and the unfolding dynamics of responses to stress. Journal of Applied Psychology, 91(5), 1037-1052.

Helbling, M. (2013). Islamophobia in the West: An introduction. In M. Helbling (Ed.), Islamophobia in Western Europe and North America: Measuring and Explaining Individual Attitudes (pp. 1-18). New York, NY: Routledge.

Hinnant, L., Sotto, P., Petrequin, S., Charlton, A., Corbet, S., Leicester, J.,Satter, R., el-Deeb, S., Karam, Z., Hadid, D., Batrawy, A. (2015). 12 Dead in Attack on Paris Newspaper Charlie Hebdo, Including the Editor. The Associated Press.

LaFree, G., \& Dugan, L. (2007). Introducing the global terrorism database. Terrorism and Political Violence, 19(2), 181-204. 


\section{Journal of Terrorism Research}

Lewin, K. (1943). Forces behind food habits and methods of change. Bulletin of the National Research Council, 108, 33-65.

Livingstone, A., Gilbert, L., Haslam, S. A., \& Sweetman, J. (June, 2010). The role of intergroup status in tendencies to play up or play down intergroup conflict. Paper presented at the International Association of Conflict Management 23rd Annual Conference, Boston, MA.

Pew Research Center. (2012). The Global Religious Landscape: A report on the size and distribution of the world's major religious groups as of 2010. Pew Research Center's Forum on Religion \& Public Life.

Piazza, J. A. (2009). Is Islamist terrorism more dangerous?: An empirical study of group ideology, organization, and goal structure. Terrorism and Political Violence, 21(1), 62-88.

Rapoport, D. C. (2002). The four waves of rebel terror and September 11. Anthropoetics, 8(1), 1-17.

Raven, B. H. (1999). Kurt Lewin address: Influence, power, religion, and the mechanisms of social control. Journal of Social Issues, 55(1), 161-186.

Reicher, S. D., Haslam, S. A., \& Platow, M. J. (2007). The new psychology of leadership. Scientific American Mind, 18(4), 22-29.

Sayare, S. (2011). A Provocative Newspaper Is Attacked in France, And Support Is Swift. New York Times.

Schmitt, E. (2015). U.S. raid in syria uncovers details on ISIS leadership and finances. New York Times.

Sedikides, C., \& Gebauer, J. E. (2013). Religion and the Self. In V. Saroglou (Ed.), Religion, Personality, and Social Behavior (pp. 46-70). New York, NY: Psychology Press.

Shaw, M., Quezada, S. A., \& Zárate, M. A. (2011). Violence with a conscience: Religiosity and moral certainty as predictors of support for violent warfare. Psychology of Violence, 1(4), 275-286.

Stern, J. (2010). Mind over martyr. Foreign Affairs, 89(1), 95-108.

Tajfel, H., \& Turner, J. C. (1979). An integrative theory of intergroup conflict. In W. G. Austin \& S. Worchel (Eds.), The Social Psychology of Intergroup Relations (pp. 33-47). Monterey, CA: Brooks/Cole Publishing Company.

Tajfel, H., \& Turner, J. C. (1986). The social identity theory of intergroup behavior. In J. T. Jost, Sidanius, J. (Ed.), Political psychology: Key readings in social psychology. (pp. 276-293). New York, NY: Psychology Press.

The White House, Office of the Press Secretary. Remarks by the president upon arrival. (2001). [Press release]. Retrieved from http://georgewbush-whitehouse.archives.gov/news/releases/2001/09/20010916-2. $\underline{\mathrm{html}}$

Ysseldyk, R., Matheson, K., \& Anisman, H. (2010). Religiosity as identity: Toward an understanding of religion from a social identity perspective. Personality and Social Psychology Review, 14(1), 60-71.

Ysseldyk, R., Matheson, K., \& Anisman, H. (2011). Coping with identity threat: The role of religious orientation and implications for emotions and action intentions. Psychology of Religion and Spirituality, 3(2), 132-148. 